\title{
Sacred spaces and new cities in the Byzantine East
}

\begin{abstract}
Some of the main trajectories of urban development in Roman Syria and Asia Minor have been studied in detail. Not much attention, however, has been paid to the fact that in some places the urban can be seen as the product of sacred. There are various examples of large rural sanctuaries that over time gained urban characteristics and eventually developed into cities. During the second wave of urbanisation in Syria in the $2^{\text {nd }} / 3^{\text {rd }}$ centuries CE, some of those "urbanised sanctuaries" were formally recognised as cities. This close entanglement between sanctuaries and the emergence of urbanity was not confined to the pagan period. Christian places of worship could trigger the urbanisation of rural places, too. Resafa, for example, developed from a small border post into a flourishing city of Sergiopolis due to the popularity of the martyrium of S. Sergios. It is remarkable that in most cases the cities that developed around sanctuaries very quickly emancipated themselves from those sanctuaries. The growing complexity of the cities' metabolism turned them into regional hubs in their own right. They proved to be very resilient and maintained their urban role even after the sanctuaries that initiated the process of urbanisation were finally abandoned.
\end{abstract}

\section{Introduction}

Stating that the cities of the Eastern Empire did not decline in late antiquity is a commonplace today. Over the last 30 years, a large array of studies has demonstrated the resilience of urbanism in this region and highlighted the vivacity of urban life in the fourth to sixth centuries CE. The master narrative changed from decline to a contingent process of transformation. ${ }^{1}$ Cities successfully adapted to changing economic, political, social, religious, and environmental re-

1 This work was supported by the Danish National Research Foundation under the grant DNRF119 - Centre of Excellence for Urban Network Evolutions (UrbNet).

See for example Kennedy (1985); Foss (1997); Avni (2011); Lavan 2012; Grig 2013; Eger (2013): 95-134; Quiroga (2016); Zanini (2016). Michael Milojević (2017, 247) labelled the sixth century as a period of "accelerated transformation" in the infinite process of urban transformation.

Ә OpenAccess. ( 2020 Laetzer/Urciuoli, published by De Gruyter. (cc) BY-NC-ND This work is licensed under the Creative Commons Attribution-NonCommercial-NoDerivatives 4.0 License. 
alities and thrived until the Umayyad period at least. This process involved the remodelling of cityscapes and the emergence of new, Christianised urban ideals.

Yet, not only did many cities of the Eastern Empire continue to prosper, new cities emerged in this period, too. This phenomenon has started to arrest attention only recently (Zanini 2003; Rizos 2017a). In most cases, the settlements were not completely new, however. Emperors promoted prospering rural communities to civic status, which sometimes entailed the adoption of a new name. ${ }^{2}$ This practice had a longstanding tradition in the Roman world. The recognition of a pre-existing settlement as a city did not necessarily have much impact on the built environment. The consequences of the status change were of mainly political, administrative, and fiscal nature. In rare instances, however, massive investments were made to turn places without a substantial previous infrastructure into urban settlements. Examples for the latter practice are Sergiupolis/ Rusafa, Anastasiopolis/Dara, and Martyropolis/Mayyāfāriqīn. ${ }^{3}$ All three cities were located in peripheral areas of the Near East that were frequently contested in antiquity. For a long time, they have been portrayed primarily as heavily fortified military bases, as garrison towns, which were constructed to close gaps in the defence system against the Sasanian Empire and potentially hostile nomadic tribes. ${ }^{4}$ They served military purposes indeed, but clearly, they were much more than just military camps. Recent research proved that they were densely populated and that they functioned as important economic hubs and religious foci. In contrast to many cities of the region with a long history that goes back to the Hellenistic period or even further, as Antioch, Cyrrhus, Hierapolis, Edessa, or Carrhae, these cities did not have a pagan past and accordingly no pre-Christian places of memory, which influenced and manipulated later urban development. They are therefore fascinating test cases for inquiries in the urban ideals of their time. Moreover, they offer insights in the entanglement between urbanism, religion, and economy. The intertwined role of economy and religion in the urbanization process is the focus of this article. Rather than giving comprehensive accounts of the individual cities, their buildings, and their development, the factors that influenced the decision to found the cities and the role of religion in their rise and success will be scrutinized.

2 For the sixth century blossom of urbanism in Byzantine North Africa, see Modéran (1996); Leone (2013).

3 Another example is Zenobia at the Euphrates; see Blétry (2017). The praxis of founding new cities continued in the Umayyad period. The most famous example is 'Anjar, located on the slopes of the Anti-Lebanon; see Hillebrand (1999).

4 For example Pollard (2000), who traces the growing militarization of cities in the Eastern Empire; see also Petersen (2013, 135-143). 


\section{Sergiupolis/Rusafa}

Sergiupolis emerged from a Late Roman castellum on the strata diocletiana, which linked the middle Orontes valley with the Euphrates. ${ }^{5}$ It developed into one of the most important Christian sanctuaries of Syria in the fifth century CE. This was due to the relics of St Sergius, a Roman soldier who is said to have been martyred in the time of Galerius at the site that was later renamed Sergiupolis. Like other military martyrs, the cult of St Sergius gained immense popularity very quickly and his shrine in Sergiupolis became a popular destination for sacred travel (Fowden 1999). Consequently, the site transformed into the main economic hub in the wider region and served as an important place of exchange between the nomads of the steppe and the sedentary population of Northern Syria. From the late fifth century CE onwards, a striking process of monumentalisation commenced. In a much-cited passage, Procopius gives an account of this process in his famous book de aedificiis:

There is a certain church in Euphratesia, dedicated to Sergius, a famous saint, whom men of former times used to worship and revere, so that they named the place Sergiopolis, and they had surrounded it with a very humble wall, just sufficient to prevent the Saracens of the region from capturing it by storm. For the Saracens are naturally incapable of storming a wall, and the weakest kind of barricade, put together with perhaps nothing but mud, is sufficient to check their assault. At a later time, however, this church, through its acquisition of treasures, came to be powerful and celebrated. And the Emperor Justinian, upon considering this situation, at once gave it careful attention, and he surrounded the church with a most remarkable wall, and he stored up a great quantity of water and thus provided the inhabitants with a bountiful supply. Furthermore, he added to the place houses and stoas and the other buildings, which are wont to be the adornments of a city. Besides this he established there a garrison of soldiers who, in case of need, defended the circuit-wall.

(Procopius, de aedificiis 2, 9)

The historicity of this report has been questioned and archaeological research at Resafa/Sergiupolis has clearly shown that the transformation of the place into a city already started in the later fifth century CE. ${ }^{6}$ Yet, more important than the exact dating of the different phases of construction is the fact that the transformation and monumentalisation of Sergiupolis happened within a relatively short

5 For the late antique Roman limes in this part of Syria, see Konrad (2001).

6 The results of research in Resafa have been published in the volumes of the Resafa publication series and in a large array of articles. For a brief overview of recent research, see Gussone (2010); Sack, Gussone, and Kurapkat (2014). 
period and that the imperial court was involved in the financing and planning of the building activities. In the decades from the later fifth century to the mid-sixth century, the city walls, various large churches, massive underground cisterns, and monumental streets were built.

After the reign of Justinian, Sergiupolis continued to prosper due to the unbroken popularity of St Sergius. This did not change in the Umayyad period, when St Sergius was revered even among Muslim arabs. In addition to the Christian basilica, a mosque was attached to the shrine of St Sergius (Sack 1996). Settlement activity peaked in the late Umayyad period when caliph Hišām b. 'Abd al-Malik (r. 724-742) took up residence at Rusafa and built a number of palaces immediately outside the city walls (Gussone - Müller-Wiener 2012; Konrad 2016). Rusafa preserved an urban character for a long time and was abandoned only in the thirteenth century in the wake of the Mongol invasion.

Today, well-preserved ruins convey a good impression of the monumentality of the city in the sixth century CE. Striking are the remarkable circuit walls that give the city the appearance of a military camp (Hof 2016; Hof [forthcoming]). Inside the walls the dominant features are the sumptuous churches, among them the central basilica with the shrine of St. Sergius. ${ }^{7}$ Colonnaded streets that start at the main gates of the city connect the churches. The main streets were $15 \mathrm{~m}$ wide and decorated with various monumental arches (Westphalen 2000). Flanked by shops, the streets served as the main places of mercantile activity and production. Other large-scale infrastructure works were underground cisterns fed by a complex system of subterranean aqueducts that collected water from the hinterland of the city (Brunke et al. 2016, 277-283).

Archaeologists and architects have investigated the ruins of Sergiupolis since the 1950s. The focus was, however, for a long time on the monumental church buildings and their decoration. Only more recently broader questions of urban life, the construction of urban space, and the life of the individual inhabitants started to play a role. The outbreak of the war in Syria, however, has prevented the full implementation of the new research agenda.

\section{Martyropolis/Mayyāfāriqīn}

Martyropolis (syr. Mayyāfāriqinn) is one of the earliest examples of a newly founded city in the late antique Eastern Empire. The city is located in the Armenian

7 Basilica A: Ulbert (1986); Basilica D: Westphalen (2000, 349-357); basilica C: Ulbert (2016). 
region of Sophanene, north of the Tigris at the river Farkin $\mathrm{Su}^{8}{ }^{8}$ It appears to have been an insignificant village until massive building activities commenced in 410 CE. ${ }^{9}$ Martyropolis then quickly rose to one of the most prominent cities of the Eastern Byzantine Empire.

The sudden rise to an important city is closely tied to Marutha of Martyropolis, at that time a prominent bishop of Mesopotamia and diplomat for the Roman state (Fowden 1997, 48-59). On various occasions between 400 and 410 CE emperor Theodosius II sent him as an imperial ambassador to the Persian Great King Yazdegerd I. As the story goes, Marutha won the confidence of Yazdegerd and was granted the right to collect the bones of all Christian martyrs in the Persian Empire. When he returned with these relics to Byzantine territory, he decided that the relics should be kept at a place in Sophanene, which then became Martyropolis. The Armenian Life of Marutha relates that

... he [Theodosius] asked him [Marutha] what he desired. And the man of god requested the emperor to fortify the city of Cop'k' with a strong wall and a church to the glory of God in the midst of city, wherein the sacrifice of Christ and praises of God might continually be performed; and that a certain number of all the saints might be brought together; and that it should be named the city of martyrs. And the emperor said: "Thy words are good, and acceptable to God are thy designs. Therefore do as thou wilt, and the expenses of the building will be paid by me, as much as is needed." And he gave treasures of gold and silver, and craftsmen from the land of the Greeks and overseers and workmen as many as were needed. ${ }^{10}$

It is difficult if not impossible to decide whether the building of the city can be attributed exclusively to the authority of bishop Marutha. Yet, the translation of the martyrs' bones and the ensuing religious significance of the place must be regarded the decisive momentum for the foundation of the city. Soon after, Martyropolis became seat of a Byzantine duke and thus an important military post at a crucial location between Armenia and Mesopotamia. The place remained important until the Mongol invasion.

The modern name of the city is Silvan. It is a small district town in the Diyarbakir province with a predominantly Kurdish population. Silvan was one of the epicentres of Kurdish-Turkish tensions and as recently as in 2015 serious clashes

8 For the history and topography of this understudied region, see Marciak (2017).

9 The claim that Martyropolis is the site of Tigranocerta, the short-lived capital of the Armenian Kingdom of king Tigranes I. is completely unfounded. Tigranocerta has been securely located at the site of Arzan on the Garzan River in Arzanene, east of Sophanene and Martyropolis, see Sinclair (1994/95); Sinclair (1996/97).

10 The Armenian Life of Marutha of Maipherkat, transl. Marcus (1932, 63-64). 
between Kurdish separatists and Turkish military forces took place in the town. The long history of political turmoil explains the almost complete lack of archaeological research in Martyropolis, which in the view of the still impressive monuments of the Byzantine time and later periods is otherwise surprising. To gather information about the monuments of Martyropolis, it is therefore necessary to resort to travel reports of the nineteenth and early twentieth century. ${ }^{11}$

The most notable remains of the late antique city are the city walls, which are still partly preserved..$^{12}$ The course of the walls can be easily traced on satellite images and allows a precise reconstruction of the extent of the walled city. It is possible to ascertain that the fortifications had an almost rectangular outline and enclosed an area of roughly 30 hectars. Inside the walls, an orthogonal street grid can be partly reconstructed. Apparently, a main street, which probably was colonnaded, ran from the east gate to the west gate. Apart from that it is difficult to assess the late antique cityscape. Today only scattered traces of ancient buildings are preserved, but when the first Western travellers visited Martyropolis before the First World War, the ruins of two monumental churches were still visible. $^{13}$

Altogether, we may assume that Martyropolis was designed according to the same urbanistic patterns as later was Sergiupolis, with fortifications, water management systems, monumental public buildings, and churches. Moreover, like in the latter city, the creation of urban space had been an imperial project, but in this case evidently mediated by the local bishop. Another similarity is the role of the city as a centre of pilgrimage. Yet, in contrast to Resafa/Sergiupolis the religious significance was not rooted in local traditions, but artificially generated by the translation of the relicts of the Persian martyrs. It was, however, the prerequisite for the formation of the city and her raison d'être.

\section{Dara/Anastasiopolis}

The vast ruins of Dara are located between Mardin and Nusaybin at the southern foothills of the Tur Abdin Mountains in South Eastern Turkey. The site is not as well preserved as Sergiupolis, but the extant remains still convey a good impression of the layout of the city and its fortifications. Dara is one of the very few

11 For early descriptions of Martyropolis/Maipherkat and its ruins, see Lehmann-Haupt (1910, 381-429); Bell (1913); Gabriel (1940).

12 For descriptions of the fortifications, see Gabriel (1940); Whitby (1984).

13 Keser-Kayaalp and Wheatley-Irving (2017) provide an analysis of the buildings the based on legacy data, most notably the archive of Gertrude Bell. 
examples of a major city that was built at a previously insignificant spot in the sixth century CE. The foundation act differs from what we have seen so far. Religious considerations did not play a role. The decision to build the city and the choice of the place were a response to the reignited Roman-Persian conflict in the first years of the sixth century CE after more than one century of largely peaceful relations between the two empires (Dignas and Winter 2007). In previous wars, Nisibis, located at the northern fringe of the Mesopotamian plain at the headwaters of the Khabur River had been the main Roman bulwark in the region. ${ }^{14}$ After the Roman defeat of $363 \mathrm{CE}$, however, the Romans had to cede Nisibis to the Persians (Greatrex and Lieu 2002,1-13). The ramifications of this loss must not be underestimated. Nisibis was at that time among the most important cities of the Eastern Empire. The almost complete lack of ancient traces in the modern city and the limited attention that archaeologists paid to the site tend to conceal this fact. The literary sources, however, clearly reveal the role of the city as a military, religious, and cultural centre that was matched only by Edessa. The economic importance of Nisibis resonates in the Sasanian-Roman peace treaties, too. The treaty of 297 CE stipulated that Nisibis was the only place along the border where the exchange of goods between the Persian and the Byzantine Empire was legal (Dignas and Winter 2007). Later agreements added further cities, but Nisibis remained the main hub of international exchange in Mesopotamia. The volume of trade must have been immense and a source of great wealth. This is confirmed by the results of recent excavations that have revealed parts of a massive basilica dating to the second and third decades of the fourth century CE. ${ }^{15}$ With five aisles and a reconstructed length of $90 \mathrm{~m}$ the basilica of Nisibis was one of the largest churches of the time.

With this city in their possession, the Persians held the key to Byzantine Mesopotamia. When they attacked in $502 \mathrm{CE}$, the Romans had difficulties to defend their territories east of the Euphrates. After this experience, a main concern was to balance the loss of Nisibis and to release the Persian pressure on the cities of Amida and Edessa. To achieve this aim, in $507 \mathrm{CE}$ the decision was taken to build a new city, Anastasiopolis, at the site of the village of Dara a close distance

14 The site is located at the Turkish-Syrian border. Today, the modern Turkish city of Nusaybin and the Syrian city of Qamishli obscure the ancient settlement. For the history of Nisibis and a description of the physical setting, see Palermo (2017, 71-79) and, largely identical, Palermo (2014).

15 Keser-Kayaalp and Erdoğan (2013). A large baptistery that was added in 359, not long before the Persian takeover. Parts of it are still standing today. 
to Nisibis. ${ }^{16}$ The local agent in the construction of the city was not the military commanders of Mesopotamia but the bishop of Amida, Thomas. The emperor entrusted him with the execution of all works and within only three years, the building of the city was completed. A detailed report of the construction work and the agents involved is given in the chronic of Pseudo-Zachariah Rhetor. ${ }^{17}$ He concludes his account with the following remark that gives a short glimpse of the cityscape:

When Kavadh [the Persian Great king] heard and tried to destroy [the city], he could not because a wall had been raised and built which was a defence for those taking refugee behind it. A large public bath and a spacious storehouse were built, and an aqueduct that came to the outskirts of the mountain, and wonderful cisterns in the city that received the water. (Pseudo Zachariah, Chron. 7, 6.)

The extant monuments of Dara/Anastasiopolis largely confirm the pieces of information given in the chronic and in other sources. Most spectacular in this respect was the recent discovery of a building complex with a mosaic inscription that confirms many details of Pseudo-Zachariah's report. ${ }^{18}$ In general, however, the amount of precise archaeological information about the site is limited. As in the case of Martyropolis, the location of Dara in a politically sensitive region has restricted research opportunities. Only recently, in 2009, Turkish archaeologists have started large-scale excavations in different areas of the city and its peripheries, but so far, only few of the very rich results have been published. ${ }^{19}$ Consequently, assumptions about the cityscape and the urban fabric must rely on reports of early travellers and a small number of studies that are based on the observation of visible remains. ${ }^{20}$

What we can see is a heavily fortified vast city area, considerably larger than Sergiupolis and Martyropolis. The line of the fortification wall is easy to follow, sections of the ramparts and some towers are still well preserved. Only recently, however, have excavations and surveys in the area between the walls and the

16 Multiple accounts of the city building have survived, see for example Ps.-Zach. HE, 7, 6; Ps.Josh. Styl. 90; Procop. Aed. II.1.4-II.3.28; Procop. Pers. I.10.13-18; II.13.16-19. See Greatrex and Lieu (2002, 74-77) for a collection of translated sources.

17 For this text and an introduction see Greatrex (2011); Rist (2004).

18 Keser-Kayaalp, Erdoğan and Palmer (2017, 165-168). Among others, the inscription mentioned bishop Thomas of Amida.

19 The best account of the new excavation results is Can and Erdoğan (2016) and KeserKayaalp, Erdoğan and Palmer (2017). The results of previous excavations in the 1980s and 1990s have never been fully disclosed, see Ahunbay (1990); Ahunbay (1991); Brands (2004). 20 Croke and Crow (1983); Nicholson 1985; Whitby (1986); Zanini (1990); Furlan (1995); Garbrecht (2004). 
proteichisma shown that this area was occupied, too (Keser-Kayaalp, Erdoğan, and Palmer 2017, 161-165). The existence of a sizable suburban area means that assumptions about the size of the settlement and the number of inhabitants cannot be based on the extent of the walled area. It seems likely that the population size was considerably larger that has previously been assumed.

Apart from the walls, the main urban features visible today are water installations. Most notable are two enormous underground cisterns that are fed by aqueducts. Likewise, remarkable is the integration of a seasonal river in the city. Massive water gates allow the water to pass through the city walls; within the city, various bridges span over the riverbed. Moreover, the recent excavations have cleared a large section of a colonnaded street with shops (Can and Erdoğan 2016, 351). The street runs from one of the city gates to the administrative and sacred centre of the city, the praetoria and the ruins of the main church, which was built on top of a massive underground cistern. Notable is also the presence of a monumental arch in this area (Brands 2004).

The cityscape of Dara featured a set of public buildings, as churches, water installations, fortifications, and colonnaded streets, that resembles what we see in Sergiupolis and in Martyropolis, but in each case they were adapted to the local topography. We must assume that structure and stratification of all three cities were relatively similar and that they functioned in analogous ways. Even though the state of research for each site is very different and impedes comparisons at a more sophisticated level, it may be concluded that a similar urban ideal resonates in the cityscape of Dara/Anastasiopolis, Martyropolis, and Resafa/Sergiupolis. ${ }^{21}$

\section{The idea of a city in the early Byzantine period}

Previous studies have elaborated on the fact that new cities of the early Byzantine period share common characteristics and differ from the cities of the previous periods. ${ }^{22}$ In a programmatic article, Zanini identified four features that in his view describe the cities of the period: they were small, fortified, Christian, and imperial (Zanini 2003, 214). A closer look at individual urban sites of this period quickly reveals that this template is too rigid. There was a large variety of urban settlements based on local needs, resources, and traditions. While

21 Further examples of new foundations of the same period like Zenobia at the Euphrates, which are not discussed here, display similar cityscapes, see Zanini (2003).

22 Brogilio and Ward-Perkins (1999); Krause and Witschel (2006); Dey (2015). 
many of the new cities were certainly much smaller than the large cities of the Imperial period, it is notoriously difficult to estimate the actual population size without extensive archaeological research. Misleading is the focus on the space that was enclosed by walls. Dara/Anastasiopolis and Sergiupolis are good examples in this regard. The territory protected by the massive fortifications is limited, but recent research has proven that the habitations stretched far beyond these walls (Keser-Kayaalp, Erdoğan, and Palmer 2017, 161-165). Monumental fortifications were of great importance, indeed. The character of the cities as protectors of the imperial border and order resonates in the massive walls that became an integral part of the urban landscape. They are imbued with symbolic meaning and highlight the reinforced character of the city as a protected area with a military garrison in a potentially hostile environment. What the walls do not do, however, is to demarcate the inhabited space. Furthermore, it is also worth mentioning that not all new Byzantine cities were heavily fortified. While strong circuit walls and towers were crucial for cities in contested areas of the empire, a place like Mokissos in Cappadocia that Justinian promoted to a city did not have walls that protected the residential areas of the settlement. ${ }^{23}$

Within cities, church buildings became focal points of the urban network and in doing so replaced and recalibrated the previous pagan landscape of power and religion. They created a sacred topography that dominated and determined urban flows. This is most evident in Resafa/Sergiupolis, where church buildings clearly form the central hubs of the urban network and dominate the urban infrastructure (Schuhmann 2016; Schuhmann 2018). We may assume that the same applied to Martyropolis, where the construction of the church for the relics of the martyrs was the keystone of the city building programme, and to Dara/Anastasiopolis.

Another central urban feature was colonnaded streets with shops and workshops. The monumental streets connected the gates with the religious and administrative centres and at the same time formed the economic centre of the settlement. They replaced the agora as the main locus of urban life and local civic identity, a process that had commenced already in the Imperial period. ${ }^{24}$ It is remarkable that still in the sixth century CE new monumental colonnaded streets were constructed. This underlines their extraordinary importance as ceremonial and economic spaces. They were a fundamental part of late antique urbanity.

23 For Mokissos, see Berger (1998). There was a fortified citadel, but the settlement itself was only protected by the peculiar topography of the site.

24 On the development of the colonnaded streets in the Near East, see Ross (2017). Also, see Dey (2015), who discusses the role of colonnaded streets in late antiquity. 
The building of new colonnaded streets also puts into perspective the idea of encroachment that frequently looms large in the discussion of public spaces in late antiquity. ${ }^{25}$ The act that in Dara/Anastasiupolis as well as in Resafa/Sergiupolis, monumentalized public space administered by the local or imperial authorities was considered essential implies that colonnaded streets must still have been fulfilling their purpose as communal spaces for economic activities and as stages for political as well as religious activities in contemporary cities.

Another main feature of urban planning was public water supply. Hydraulic installations of large scale were built to collect water from the surrounding areas and, particularly relevant in dry areas, to store water inside the city for periods of drought or siege. At Dara and Resafa, massive underground cisterns attest to the immense efforts to manage the water supply. Moreover, public baths continued to be landmarks of urbanity. ${ }^{26}$

In general, the construction and even more so the maintenance of the monumental urban infrastructure required a high degree of organisation and presupposed the existence of institutions, which were able to exert control. Unfortunately, it is difficult to populate these buildings with people and activities, because the focus of research not only at the sites under scrutiny but also in most other late antique cities of the Near East has been mainly on architecture. Moreover, knowledge of city life beyond monumental, mostly public buildings is in general rudimentary. More research in the living quarter of non-elites is required to understand how the majority of the citizens lived in their cities and how they made use of the urban landscape. Even at Sergiupolis little evidence of residential quarters of the sixth century exists. ${ }^{27}$

The relative homogeneity of the urban layout of the new cities at the eastern frontier is to a large part the result of the engagement of the imperial court in their formation. In all three cases discussed here, city building relied almost exclusively on imperial funding. Moreover, the literary sources state explicitly that architects and craftspeople were sent from the imperial centres to take part in the building activities. The cities reflected an urban ideal that was conceived at the imperial court in the fifth and sixth century CE. This ideal can also be traced in new foundations in other border regions of the Byzantine Empire, but it rarely manifests itself as clearly as at the Eastern frontier (Zanini 2003; Dey 2015).

Despite the strong impact of the imperial court on the physical appearance, the cities must not per se be labelled Imperial. In Martyropolis and in Dara/Ser-

25 See Jacobs (2009) for a balanced discussion of the evidence for encroachment.

26 On baths and bathing in late antiquity, see DeForrest (2019, 189-206) with further literature.

27 There have been exceptions of course, most notably a project on the urban structure of the city directed by Stephan Westphalen (2000) in the 1990s. 
giupolis, the Imperial investment was a response to local and regional factors that facilitated and, most importantly, sustained the urbanisation process: religion and economy.

\section{Sacralised economy and the formation of new cities in the Near East}

Peregrine Horden and Nicholas Purcell developed the idea of sacralised economies to characterize the entanglement between economic activity and religious practice in the ancient Mediterranean world (Horden and Purcell 2000, 432449). Religious festivals and fairs encapsulate this interconnectedness best. The seasonal movement of large crowds to sanctuaries played a major role for trade and created nodal points for the local, regional, and international exchange of goods. They offered lucrative business opportunities for the local population and had a huge impact on the local economy during the festival season. The visitors had to pay for accommodation, food, and services and they made endowments and donations. Moreover, festivals created the opportunity for trade that was not a direct response to the demands of the religious activities and the people participating in them. The predictable gathering of large crowds made them attractive as market places for all sorts of goods. Yet, few attempts have been made to further conceptualise the intimate relation between religious travel, economy and the city (Kristensen 2017; Collar and Kristensen [forthcoming]).

For the late antique East, a wide range of sources attests to the continued importance of this entanglement and its impact on both rural and urban economies. ${ }^{28}$

Gregory of Tours, for example, mentions an annual fair at Edessa, which was attended by large crowds.He reports "...those who come from various regions for prayer and for traffic are given permission to sell and buy without any taxes being levied for a period of 30 days" (Gregory of Tours, Glory of the Martyrs, 32). The close connection between trade and religion is very explicit here. In general, we see an increased economic activity due to the presence of pilgrims and the attraction of festivals and fairs taking place during religious holidays for the inhabitants of the surrounding regions. This applies to Sergiupolis in particular. The appeal of the Sergius sanctuary is well attested. This quickly resulted in a rearrangement of local and regional networks (Fowden 1998, 101-129; Schuh-

28 For an overview of fairs in late antique Near East, see De Ligt (1993, 70 - 75); Binggeli (2007, 2012). The focus of the latter author is on the Islamic period. 
mann 2018). Sergiupolis turned into a central hub and the impact of this shift must not be underestimated. Not only was the flow of people, but also of goods recalibrated. This process was closely intertwined with the urbanisation of the site. What is crucial here is the contingency of the development. The rapid rise of Sergiupolis to the main centre of north-western Syria was not the result of a centralised attempt to reinforce imperial power in a contested border area, but from the attraction of the cult of St Sergius and its appeal to the nomads of the Syrian steppe. With their support, the Byzantine emperors acknowledged the new economic and religious topography. The religious allure of the site nourished economic success that was necessary to sustain a city in a marginal region. A sustainable city, however, was the prerequisite for the maintenance of a large military garrison. This demonstrates the close entanglement between religious, economic and military aspects in the construction of urban spaces. After the Byzantine retreat from Syria, the central position that the city had taken in the regional and international economic network not only secured the survival of Resafa/Sergiupolis, but also ushered in a new floruit under Umayyad rule. The Byzantine state had heavily invested in the urbanisation of the city, but it was neither dependent on Byzantine subsidies nor just a disembedded garrison town.

We may assume that similar mechanisms were at play at Martyropolis in the fifth century. The reputation of bishop Marutha and the deposition of the relics of the Persian Martyrs will have had a direct impact on regional networks and economic flows. This must have been quickly recognized or even anticipated by the imperial court and triggered the heavy investment in the urbanisation of Martyropolis. Finally, the long survival of the city and the continued prosperity in the Islamic period proves the city's role as an economic hub.

Dara/Anastasiopolis developed in a profoundly different way. The foundation of the city, its quick growth, and its economic success were created very artificially. Sustaining a large city at close distance to a prominent urban centre like Nisibis required not only a heavy Imperial investment, but also a very specific geopolitical situation. ${ }^{29}$ The latter guaranteed substantial economic power to the new city, because the Persian-Byzantine peace treatises conceded the rare privilege to exchange goods between the Byzantine and Persian empires not only to Nisibis, but also to Dara/Anastasiopolis. ${ }^{30}$ This secured an eminent role in long distance trade. On the long run, however, the reliance on this clause and Byzantine security concerns at the Persian border proved to be detrimental.

29 Dara/Anastasiopolis can be considered disembedded, taking up a term coined for newly funded capitals. On this concept, see Joffee (1998).

30 The peace of 561 CE stipulates that the border can be crossed only at Nisibis and Dara; see Menander frg.6.1.314-97, trans. Greatrex and Lieu (2002, 132). 
The Arab conquest of Mesopotamia rendered all Byzantine-Persian trade regulations irrelevant. Mesopotamia in its entirety stood under Arab rule and the military, economic, and political incentives to support Dara/Anastasiopolis were no longer valid. Within a short period, Dara/Anastasiopolis lost its importance and was largely abandoned. The neighbouring city of Nisibis, however, traditionally the main religious centre of the region, well-integrated with the hinterland, prevailed and never ceased to play a role as a regional centre.

\section{Conclusion}

The foundation of new cities at the eastern fringes of the Byzantine Empire in the fifth and sixth century CE did not follow a uniform rationale. In the case of Anastasiopolis/Dara, the emergence of the city was a response to very specific military and economic needs. The loss of the eminent city of Nisibis to the Sasanians needed to be balanced to protect the military and economic position of the Byzantine Empire in Northern Mesopotamia. In Martyropolis and Sergiupolis however, we see a complex interplay of local, regional, and imperial agents involved in the creation of urban space. Yet, it appears that the religious significance and the ensuing economic importance of both places were the driving forces in the urbanization process. At Sergiupolis, the relicts of a local martyr gained unforeseeable fame and fostered the rise of a previously inconspicuous place to a regional centre of high religious prestige, pilgrimage and, consequently, economic importance. The subsequent imperial investment acknowledged the position of the place and cast it in a physical form that mirrored the urban ideal of the time. Moreover, the imperial endorsement of the site and the cult of St Sergius tied the new city closely to the empire. Yet, the decision to monumentalize the place was not part of an overarching imperial strategy to strengthen the Eastern frontier, but the result of a contingent process that was driven by regional trajectories. In the case of Martyropolis, the translation of a large number of relicts increased the sacredness of the place. This was the result of the agency of one individual, bishop Marutha, who at that time was an important figure at the Byzantine court. The motifs that made him choose the site of Martyropolis remain unknown, but there is no indication of imperial involvement in the decision-making process. The heavy involvement in the construction and fortification of the city should therefore be considered a response to local developments, too.

Despite the different factors that fostered urbanisation, the study of the archaeological remains and the written sources show that the three cities adhered to similar urbanistic models. The urban topography on the one hand emphasizes military power and puts emphasis on the role of the cities as protectors of the 
land. On the other hand, the cityscape displays a pronounced desire for monumentality: Colonnaded streets, plazas, arches, public bath buildings, churches, and long-distance aqueducts continue the tradition of Classical cities in the Mediterranean world. The resemblance is no coincidence, because in all three cases urbanization and monumentalisation of the cityscape depended almost exclusively on imperial funding and support. The cities mirror an urban ideal that had been developed at the imperial court. Yet, the agents who negotiated and oversaw the construction of these cities were primarily clergymen. They overtook duties, which previously had been in the hands of the local councils.

The sustainability of these new cities that were located in contested frontier zones with limited natural resources depended to a large degree on the embeddedness with the hinterland and the establishment of far-reaching trade networks. A very efficient way of securing the integration of a place in the wider economic network was religious capital. In fact, religious significance appears to have been the premise for the creation of sustainable urban sites. The network of new cities along the border is therefore not only a response to defensive needs than the result of the emergence of new religious and economic networks, which had developed under Christian auspices. This was not a new phenomenon. Forerunners were the urban centres of the Syrian and Mesopotamian steppe in the late Hellenistic and early Roman period. Palmyra, Hatra, and Emesa developed along similar lines. Their emergence as cities was symbiotic with their rise to religious and economic centres. In general, the interdependence of sacred travel and mercantile activity seems to be one key to an understanding of the formation of sustainable large cities in the marginal areas of Syria and Mesopotamia in both antiquity and late antiquity.

\section{Bibliography}

Ahunbay, Metin. "Dara-Anastasiopolis." Kazı Sonuçları Toplantısı 12:1 (1990): 391-397.

Ahunbay, Metin. "Dara-Anastasiopolis 1990 Yılı Çalışmaları.” Kazı Sonuçları Toplantısı 13:1 (1991): $197-203$.

Avni, Gideon. "From Polis to Madina Revisited - Urban Change in Byzantine and early Islamic Palestine." Journal of the Royal Asiatic Society, Series 3, 21:3 (2011): 301-329.

Bell, Gertrude. Churches and Monasteries of the Tûr 'Abdîn and Neighbouring Districts. Heidelberg: C. Winter's Universitätsbuchhandlung, 1913.

Binggeli, André. "Foires et pèlerinages sur la route du hajj. À propos de quelques sanctuaires chrétiens et musulmans dans le sud du Bilâd al-Shâm d'après le Kitâb al-azmina d'lbn Mâsawayh (9e s.)." ARAM 19 (2007): 559-582. 
Binggeli, André. "Annual Fairs, Regional Networks, and Trade Routes in Bilād al-Shām (SixthTenth Centuries)." In Trade and Markets in Byzantium edited by Cécile Morrison, 281-296. Washington, DC: Dumbarton Oaks Research Library \& Collection, 2012.

Berger, Albrecht. "Viranşehir (Mokisos), eine frühbyzantinische Stadt in Kappadokien." Istanbuler Mitteilungen 48 (1998): 349-429.

Blétry, Sylvie. "L'urbanisme et l'habitat de la ville de Zénobia-Halabiya. Résultats de la mission franco-syrienne (2006-10)." In New Cities in Late Antiquity: Documents and Archaeology edited by Efthymios Rizos, 137-155. Bibliothèque de l'Antiquité Tardive 35. Turnhout: Brepols.

Brands, Gunnar. “Ein Baukomplex in Dara-Anastasiopolis.” Jahrbuch für Antike und Christentum 47 (2004): 144-155.

Brogiolo, Gian Pietro and Bryan Ward Perkins, eds., The Idea and Ideal of the Town Between Late Antiquity and the Early Middle Ages. Leiden: Brill, 1999.

Brunke, Hagan et. al., "Thinking Big. Research in Monumental Constructions in Antiquity." In Space and Knowledge. Topoi Research Group Articles, eTopoi edited by Gerd Graßhoff and Michael Meyer, 250-305. Journal for Ancient Studies, Special Volume 6, 2016.

Can, Birol and Nihat Erdoğan. "Dara. Bizans - Sasani Sınırında Bir Garnizon Kenti ve Kazıları.” In Anadolu’nun Zirvesinde Türk Arkeolojisinin 40 Yılı, Atatürk Üniversitesi Edebiyat Fakültesi Arkeoloji Bölümü 40. Kuruluş Yılı Armağanı edited by M.A. Yılmaz H. Kasapoğlu, 347-371. Ankara: Bilgin Kültür Sanat Yayınları, 2014.

Collar, Anna C. F. and Troels M. Kristensen, eds. Pilgrimage and Economy in the Ancient Mediterranean, Religions in the Graeco-Roman World. Leiden: Brill, forthcoming.

Croke, Brian and James Crow. "Procopius and Dara." Journal of Roman Studies 73 (1983): 143-159.

De Ligt, Lukas. Fairs and Markets in the Roman Empire: Economic and Social Aspects of Periodic Trade in a Pre-industrial Society, Dutch Monographs on Ancient History and Archaeology 11 Amsterdam: Gieben.

DeForrest, Dallas. "Baths, Christianity, and Bathing Culture in Late Antiquity." In Oxford Handbook of Early Christian Archaeology edited by William R. Caraher, Thomas W. Davis, and David K. Pettegrew, 189-206. Oxford: Oxford University Press, 2019.

Dey, Hendrik W. The Afterlife of the Roman City. Architecture and Ceremony in Late Antiquity and the Early Middle Ages. New York: Cambridge University Press, 2015.

Dignas, Beate and Engelbert Winter. Rome and Persia in Late Antiquity. Neighbours and Rivals. Cambridge: Cambridge University Press, 2007.

Eger, Asa. "(Re)Mapping Medieval Antioch: Urban Transformations from the Early Islamic to the Middle Byzantine Periods." Dumbarton Oakes Papers 67 (2013): 95-134.

Foss, Clive. "Syria in Transition, A. D. 550-750: An Archaeological Approach." Dumbarton Oaks Papers 51 (1997): 189-269.

Fowden, Elizabeth Key. The Barbarian Plain: Saint Sergius between Rome and Iran. Berkeley: Los Angeles and London, 1999.

Furlan, Italo. "Cisterne a Dara." In Arte profana e arte sacra a Bisanzio edited by Antonio lacobini and Enrico Zanini, 51-63. Milion 3. Rome: Argos, 1995.

Gabriel, Albert. Voyages archéologiques dans la Turquie orientale. Paris: de Boccard, 1940.

Garbrecht, Günther. "Procopius und die Wasserbauten von Dara." In Wasserbauten im Königreich Urartu und weitere Beiträge zur Hydrotechnik in der Antike edited by 
Christoph Ohlig, 105-132. Schriften der Deutschen Wasserhistorischen Gesellschaft 5. Norderstedt: Books on Demand GmbH, 2004.

Greatrex, Geoffrey and Samuel N. C. Lieu, eds. The Persian Wars. Part II. AD 363-630.

A Narrative Sourcebook. London and New York: Routledge, 2002.

Greatrex, Geoffrey, ed. The Chronicle of Pseudo-Zachariah Rhetor: Church and War in Late Antiquity. Liverpool: Liverpool University Press, 2011.

Grig, Lucy. "Cities in the "Long” Late Antiquity, 2000-2012 - a Survey Essay." Urban History 40 (2013): $554-566$.

Gussone, Martin. "Resafa-Sergiupolis/Rusafat Hisham, Syrien. Pilgerstadt und Kalifenresidenz. Neue Ansätze, Ergebnisse und Perspektiven.” Zeitschrift für Orientarchäologie 3 (2010): 102-129.

Gussone, Martin and Martina Müller-Wiener, "Resafa-Rusafat-Hisham, Syria. 'Long-Term Survival' of an Umayyad Residence-First Results of the Extended Surface Survey." In Proceedings of the 7th International Congress of the Archaeology of the Ancient Near East, 12. -16. April 2010, London, Vol. 2 edited by Roger Matthews and John Curtis, 569-584. Wiesbaden: Harassowitz, 2012.

Hillebrand, Robert. "“'Anjar and the early Islamic urbanism.” In: The Idea and the ideal of the Town between Late Antiquity and Early Middle Ages edited by Gian Pietro Brogiolo and Bryan Ward-Perkins, 59-98. Leiden: Brill, 1999.

Hof, Catharine. "The Late Roman City Wall of Resafa/Sergiupolis (Syria). Its Evolution and Functional Transition from Representative over Protective to Concealing." In Focus on Fortification edited by Rune Frederiksen et al., 377-392. Oxford: Oxbow, 2016.

Hof, Catharine. Resafa-Sergiupolis / Rusafat Hisham. Stadtmauer. Resafa 9,1 (forthcoming). Horden, Peregrine and Nicholas Purcell. The Corrupting Sea. A Study of Mediterranean History. Oxford: Blackwell, 2000.

Jacobs, Ine. "Encroachment in the eastern Mediterranean between the fourth and the sixth century CE.” Ancient Society 39 (2009): 203-243.

Joffee, Alexander H. "Disembedded Capitals in Western Asian Perspective." Comparative Studies in Society and History 40 (1998): 549-580.

Kennedy, Hugh. "From Polis to Madina. Urban Change in Late Antique and Early Islamic Syria." Past and Present 106 (1985): 3-27.

Keser-Kayaalp, Elif and Nihat Erdoğan, "The Cathedral Complex at Nisibis." Anatolian Studies 63 (2013): 137-154.

Keser-Kayaalp, Elif, Nihat Erdoğan, and Andrew Palmer, "Recent research on Dara Anastasiopolis." In New Cities in Late Antiquity: Documents and Archaeology edited by Efthymios Rizos, 153-175. Bibliothèque de l'Antiquité Tardive 35. Turnhout: Brepols, 2017.

Keser-Kayaalp, Elif and Linda Wheatley-Irving, "Late Antique Architectural Sculpture at the Mayyāfāriqīn Mosque (Silvan Ulu Cami)." In: Central Periphery? Art, Culture and History of the Medieval Jazira (Northern Mesopotamia, 8th-15th centuries) edited by Lorenz Korn and Martina Müller-Wiener, 125-152. Wiesbaden: Reichert, 2017.

Konrad, Michaela. Der spätrömische Limes in Syrien. Archäologische Untersuchungen an den Grenzkastellen von Sura, Tetrapyrgium, Cholle und in Resafa, Resafa V. Mainz: Philipp von Zabern, 2001.

Konrad, Christoph B. "Resafa/ar - Rusafa. Die Paläste von Rusafat Hišam. Ergebnisse der Untersuchung von zwei der frühislamischen Großbauten der Siedlung extra muros." In Wohnen - Reisen - Residieren. Herrschaftliche Repräsentation zwischen temporärer 
Hofhaltung und dauerhafter Residenz in Orient und Okzident edited by Dorothée Sack, Daniela Spiegel and Martin Gussone, 139-151. Petersberg: Imhof Verlag, 2016.

Krause, Jens-Uwe and Christian Witschel, eds. Die Stadt in der Spätantike - Niedergang oder Wandel? Akten des internationalen Kolloquiums in München am 30. und 31. Mai 2003, Historia. Einzelschriften 190. Stuttgart: Steiner, 2006.

Kristensen, Troels Myrup. "Excavating Meriamlik: Sacred Space and Economy in Late Antique Pilgrimage." In Excavating Pilgrimage: Archaeological Approaches to Sacred Travel and Movement in the Ancient World edited by Troels Myrup Kristensen and Wiebke Friese, 224-244. London: Routledge, 2017.

Lavan, Luke. "From Polis to Emporion? Retail and Regulation in the Late Antique City." In Trade and Markets in Byzantium edited by Cécile Morrison, 333-377. Washington, DC: Dumbarton Oaks Research Library \& Collection, 2012.

Lehmann-Haupt, Carl Friedrich. Armenien einst und jetzt. Vom Kaukasus zum Tigris und nach Tigranokerta. Berlin: Behr's, 1910.

Leone, Anna. The End of the Pagan City. Religion, Economy, and Urbanism in Late Antiquity North Africa. Oxford: Oxford University Press, 2013.

Marciak, Michat. Sophene, Gordyene, and Adiabene: Three Regna Minora of Northern Mesopotamia. Leiden: Brill 2017.

Marcus, Ralph. "The Armenian Life of Marutha of Maipherkat." The Harvard Theological Review 25:1 (1932): 47-71.

Milojević, Michael. "Forming and Transforming Proto-Byzantine Urban Public Space." In The Fifth Century. End or Beginning? edited by Pauline Allen and Elizabeth Jeffreys, 247-262. Byzantina Australiensia 10. Leiden: Brill, 1996.

Modéran, Yves. "La renaissance des cités dans l'Afrique du Vle siècle d'après une inscription récemment publiée." In La fin de la cité antique et les débuts de la cité médiévale edited by Claude Lepelley, 85-114. Bari: Edipuglia, 1996.

Nicholson, 0. “Two Notes on Dara." American Journal of Archaeology 89:4 (1985): 663-671.

Palermo, Rocco. "Nisibis, Capital of the Province of Mesopotamia: Some Historical and Archaeological Perspectives." Journal of Roman Archaeology 27 (2014): 456-471.

Palermo, Rocco. On the Edge of Empires. North Mesopotamia during the Roman Period (2nd-4th c. CE). London: Routledge, 2019.

Petersen, Leif I. R. Siege Warfare and Military Organization in the Successor States (400-800 AD) Byzantium, the West and Islam. Leiden: Brill, 2013.

Pollard, Nigel. Cities, Soldiers, and Civilians in Roman Syria. Ann Arbor: University of Michigan Press, 2000.

Quiroga, Jorge López. "Early Byzantine Urban Landscapes in the Southwest and Southeast Mediterranean." In Proceedings of the 23rd International Congress of Byzantine Studies, Belgrade, 22-27 August 2016 edited by Smilja Marjanović-Dušanić, 69-106. Belgrade: The Serbian National Committee of AIEB, 2016.

Rist, Josef, "Der Bau des ostsyrischen Stadt Dara (Anastasiupolis). Überlegungen zum Eigengut in der Kirchengeschichte des Ps.- Zacharias Rhetor." in Syriaca II. Beiträge zum 3. Deutschen Syrologen-Symposium in Vierzehnheiligen 2002 edited by Martin Tamcke, 243-266. Münster: Lit, 2004.

Rizos, Efthymios, ed. New Cities in Late Antiquity: Documents and Archaeology. Bibliothèque de l'Antiquité Tardive 35. Turnhout: Brepols, 2017. 
Sack, Dorothée. Die Grosse Moschee von Resafa - Rușāfat Hišām. Resafa 4. Mainz: Philipp von Zabern, 1996.

Sack, Dorothée, Martin Gussone, and Dietmar Kurapkat, "A Vivid City in the 'Syrian Desert' The case of Resafa-Sergiupolis / Rusafat Hisham." In Settlement Dynamics and Human-Landscape Interaction in the Steppes and Deserts of Syria edited by Daniele Morandi Bonacossi, 257-274. Wiesbaden: Harrassowitz Verlag, 2014.

Saradi, Helen G. The Byzantine City in the Sixth Century. Literary Images and Historical Reality. Athens: Society of Messenian Archaeological Studies, 2006.

Schuhmann, Axel. "Die Sakrallandschaft von Resafa (Sergiupolis) - Liturgie einer Pilgerstadt an der östlichen Peripherie." In Acta XVI Congressus internationalis archaeologiae christianae. Romae (22-28.9.2013): Costantino e i costantinidi: l'innovazione costantiniana, le sue radici e i suoi sviluppi edited by Olof Brandt, Vincenzo Fiocchi Nicolai, and Gabriele Castiglia, 1805-1820. Città del Vaticano: Pontificio Istituto di Archeologia Cristiana, 2016.

Schuhmann, Axel. "Die Entwicklung der Sakraltopographie von Resafa/Sergiupolis und die Inszenierung des Ortes als Stätte des Sergiosmartyriums." In Für Seelenheil und Lebensglück. Das byzantinische Pilgerwesen und seine Wurzeln edited by Despoina Ariantzi and Ina Eichner, 59-72. Mainz: Verlag des Römisch-Germanischen Zentralmuseums,2018.

Sinclair, Thomas A. "The Site of Tigranocerta I." Revue des Études Arméniennes 25 (1994/95): $183-254$.

Sinclair, Thomas A. "The Site of Tigranocerta II." Revue des Études Arméniennes 26 (1996/97): 51-117.

Ulbert, Thilo, Die Basilika des Heiligen Kreuzes in Resafa-Sergiupolis, Resafa 2. Mainz: Philipp von Zabern, 1986.

Ulbert, Thilo, ed. Forschungen in Resafa - Sergiupolis, Resafa 7. Berlin: De Gruyter, 2016.

Westphalen, Stephan. “Resafa. Bericht über die Ausgrabungen 1997 bis 1999.” Damaszener Mitteilungen 12 (2000): 325-365.

Wickham, Chris. Framing the Early Middle Ages. Europe and the Mediterranean,400-800. Oxford: Oxford University Press, 2005.

Whitby, Michael. "Procopius Description of Martyropolis (De Aedificiis III.2.10-14)." Byzantinoslavica 14 (1984): 177-182.

Whitby, Michael. "Procopius' Description of Dara. Buildings II 1-3." In The Defence of the Roman and Byzantine East. Proceedings of a Colloquium Held at the University of Sheffield in April 1986 edited by Philip Freeman and David Kennedy, 737-783. British Archaeological Reports, International Series 297. Oxford: B. A. R., 1986.

Zanini, Enrico. "La cinta muraria di Dara. Materiali per un'analisi stratigrafica." In Costantinopoli e l'arte delle province orientali edited by Fernanda de' Maffei, Alessandra G. Guidobaldi, and Claudia Barsanti, 229-264. Milion, Studi e ricerche d'arte bizantina 2. Rome: Campisano, 1990.

Zanini, Enrico. "The Urban Ideal and Urban Planning in Byzantine New Cities of the Sixth Century A.D." In: Theory and Practice in Late Antique Archaeology edited by Luke Lavan and William Bowden, 196-223. Leiden: Brill, 2003.

Zanini, Enrico. "Coming to the End: Early Byzantine Cities after the mid-6th Century." In Proceedings of the 23rd International Congress of Byzantine Studies, Belgrade, 22-27 
August 2016 edited by Smilja Marjanović-Dušanić, 127-140. Belgrade: The Serbian National Committee of AIEB, 2016. 